\title{
EVALUATION OF LOCAL MACHINE PERFORMANCE FOR FABA BEAN CURSHING
}

\author{
*R. A. A. Ahmed
}

\section{ABSTRACT}

The main objective of this work was to performance evaluate for locally made small machine for faba bean crushing at moisture content of $9.5 \%$ $d b$. The performance of faba bean crushing machine was evaluated at different hammer drum speeds (1000, 1250, 1500 and 1750 r.p.m ), feeding rates (60,90 and $120 \mathrm{~kg} / \mathrm{h}$ ) and sieves holes diameter (2, 4 and $6 \mathrm{~mm})$,were evaluated on the basis of curshing productivity $(\mathrm{Mg} / \mathrm{h})$, efficiency machine (\%), total energy consumed ( $k W . h / M g$ ), Faba bean mean particle size \%. The results indicated that the highest productivity was $118 \mathrm{~kg} / \mathrm{h}$ and productivity efficiency $99 \%$ obtained at 1750 r.p.m hammer drum speed, $6 \mathrm{~mm}$ sieves holes diameter and $120 \mathrm{~kg} / \mathrm{h}$ feeding rate. The best result for crushed faba bean particle size was obtained at $1750 \mathrm{rpm}, 2 \mathrm{~mm}$ sieves holes diameter and $60 \mathrm{~kg} / \mathrm{h}$ feeding rate. While the minimum specific energy $7.50 \mathrm{~kW} . \mathrm{h} / \mathrm{Mg}$ was obtained at $1750 \mathrm{rpm}, 6 \mathrm{~mm}$ sieves holes diameter and $120 \mathrm{~kg} / \mathrm{h}$ feeding rate.

\section{INTRODUCTION}

I n Egypt, cultivated Faba bean (Vicia faba OL.) is used as human food and as animal feed. The faba bean productivity in Egypt is the highest in Mediterranean region where the average cultivated area is about $204,800 \mathrm{fed} /$ year with medium yield around of $1.88 \mathrm{Mg} /$ fed (Ministry of Agriculture, 2012). Faba bean is an important crop in Egypt consumption where green and dry seeds because it contains percentage of a high-quality protein up to $28 \%$ and the carbohydrates $58 \%$ in addition to many of vitamins and other nutrients so ( Singh et al., 2012). EL. Hadidi et al (1996) reported that, a small vertical milling machine was improved and tested. The behavior of particles and force acting on them during grinding were studied in order to achieve the optimum condition for milling operation.

*Assoc. Prof of Agric. Power and mach. Eng. Dept., . Fac .of Agr. Eng. Al-Azhar U . Cairo. 
The effect of some parameters such as revolving speed, discs clearance and feeding rate on milling efficiency of wheat and maize grains. Results indicated that disc speed in the range of ( 300 to 350 r.pm), disc clearance of $(1.5-2 \mathrm{~mm})$ and feeding rate of $250 \mathrm{~kg} / \mathrm{h}$ may be considered as optimum factors in milling process of wheat and maize grains. The energy requirements are higher in maize as compared with that needed for wheat grains at all speeds, clearance and feeding rates. Yossef et al. (1982) mentioned that the faba beans grain size is an important factor during handling and cooking. time required Kozmin ( 1988 ) classified the types of milling equipment according to the principles of action of their working organs upon the treated product as follow:

$1-$ Cutting (chipping off) machines.

2 - Pressing (crushing) machines.

3 - Machine acting by free impact.

Milling equipment may depend upon a single one of these actions or upon a combination of two or more. Mille also can be designed and frequently are to produce attrition and impact grinding. Mousa et al., (2016) mentioned that the results the crushing machine productivity increased with the increase of both hammers speed and sieve hole diameter while specific energy consumed decreased with the increase of both hammers speed and sieve hole diameter. Hassan (1994) showed that grinding capacity increased and grinding energy decreased as fineness of grinding increased by increasing screen size from $3.2 \mathrm{~mm}$ to $6.35 \mathrm{~mm}$ which in turn gave an increase of $68.1 \%$ in grinding capacity and a decrease of $55 \%$ in grinding energy. El-Gayar and Bahnas (2002) studied some factors affecting on hammer mill to produce garlic power such as three hammer tip speeds $(13.82,18.43$ and $23.04 \mathrm{~m} / \mathrm{s})$, two feed rates $(27.00$ and $43.20 \mathrm{~kg} / \mathrm{h}$ ) two screen hole diameters $(1$ and $2 \mathrm{~mm})$. They indicated that the highest milling capacity was obtained at $23.04 \mathrm{~m} / \mathrm{s}$ hammer tip speed. Hegazy et al, (2002) indicated that increasing hammer revolving speeds from 1000 to $2500 \mathrm{rpm}$ cause a corresponding increase in the machine productivity. Garg et al. (2010) used a continuous grinding at different speeds of the crushing varied from 800 to $1200 \mathrm{rpm}$ for sieve 
sizes of $0.5,1.0$ and $2.0 \mathrm{~mm}$. They found that if the speed of the crushing increases, power consumption will increase.

The main objective of this work is study of some factors affecting Faba bean crushing and evaluating a small crushing machine for locally mode suitable for Faba bean crushing production

\section{MATERIALS AND METHODS}

The experiments were carried out at Faculty of Agricultural Engineering, Al-Azhar University, Cairo during the year of 2017 for small crushing machine local manufactured.

\section{A - Materials :}

\section{1 -Faba bean Variety.}

Experiments were carried out on Faba bean variety Misr 1. Some physical and mechanical properties of the used Faba bean are given in table ( 1 ) this properties the principles was related with operating factors optimum. The moisture content of Faba bean at the time of experiment was $9.5 \%$ d.b.

Table ( 1 ) Some physical and mechanical properties of Faba bean.

\begin{tabular}{|c|c|c|}
\hline Parameters & Mean & CV $(\%)$ \\
\hline Moisture content db( \%) & 9.50 & 1.23 \\
\hline Length, mm & 13.50 & 4.66 \\
\hline Width, mm & 10.60 & 3.45 \\
\hline Thickness, mm & 6.45 & 3.23 \\
\hline Mass, g & 2.55 & 5.20 \\
\hline Friction angle ( on steel) & 21.45 & 2.78 \\
\hline repose angle, degree & 13.55 & 3.58 \\
\hline Rupture force, $\mathrm{N}$ & 150 & 6.40 \\
\hline
\end{tabular}

\section{2 - Crushing machine :}

- The crushing machine installation used in this study as shown fig (1).

\section{-Frame:}

The overall frame is constructed from iron L- sections ( $60 \times 60 \times 3 \mathrm{~mm}$ ) welded together and fixed to the ground by four steel screws.

\section{-Feeding hopper:}

The feeding hopper was installed to feed the Faba bean into the crushing machine. The sides of this hopper sloped gradually $\left(27^{0}\right)$ to keep the 
flow of Faba bean at constant rate, the slope of controlling gate was changed by sliding plate using an arm operates manually. The feeding hopper was fixed on top frame using five steel bolts. The gate was drilled on the side of hopper to control the feeding rate of Faba bean seeds from hopper to crushing unit.

\section{-Crushing machine:}

Crushing process was accomplished by using a hammer crush. The hammer crush was preferred because of its simplicity, acting by free impact and ease of operation. The crushing machine consisted of free movement knifes and mounted on four horizontal shafts. It is made from flat spring steel with dimensions of 114, 45 and $6 \mathrm{~mm}$ for length, width and thickness respectively as shown in Fig. 1. The shafts are fixed on flanged a large cylinder powered by electric motor.

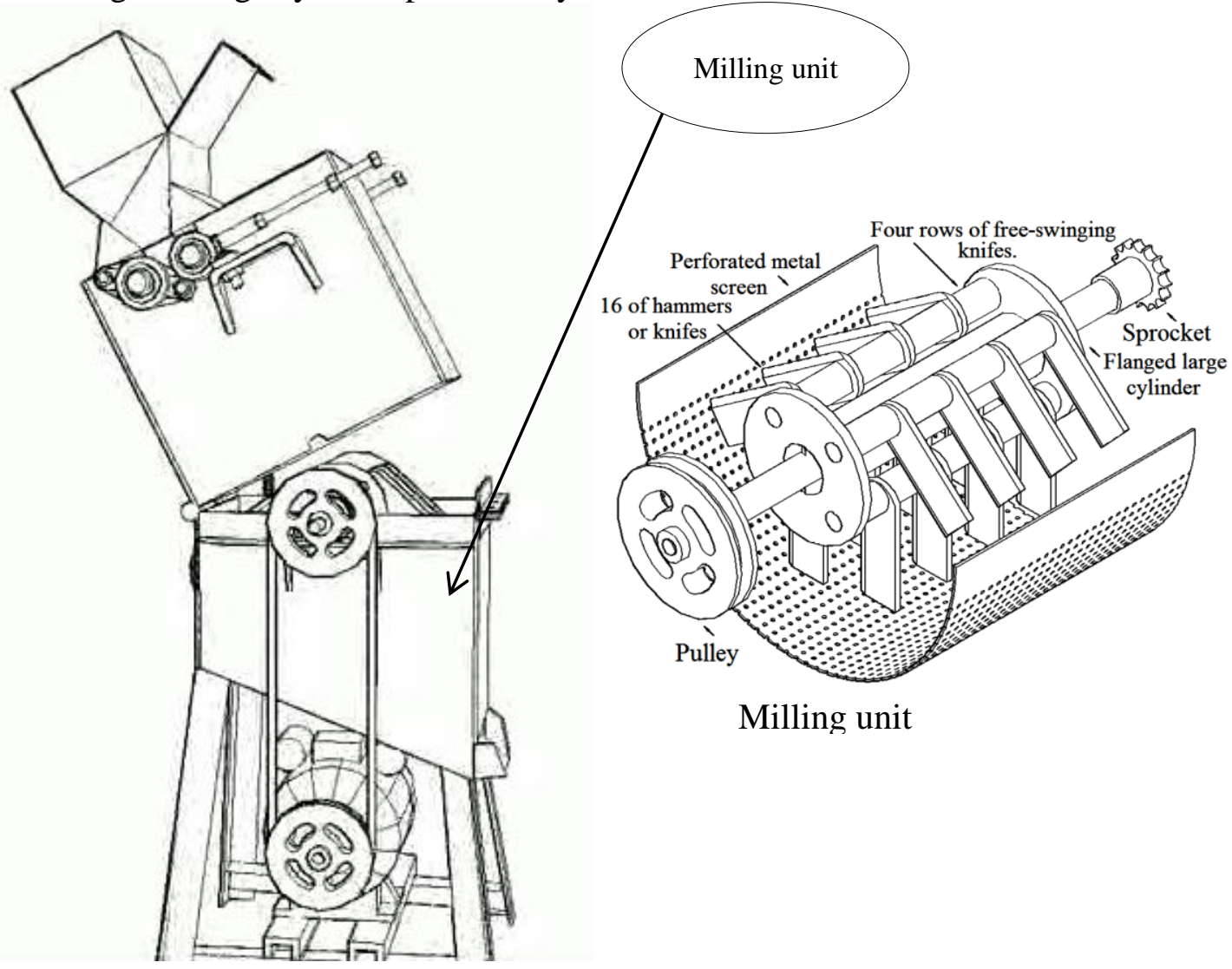

Fig.(1); Crushing machine ( Mousa et al., 2016). 


\section{-Source of power:}

The power source utilized to drive the crushing machine was an electrical motor ( 1400 r.p.m , $1.3 \mathrm{~kW}$ ) the power from the source was transmitted crushing machine by means of pulley and $\mathrm{V}$ belt.

\section{B - Methods}

The crushing experiments carried out to optimize some operating parameters affecting the performance of crushing machine these parameters are:

- Four hammer drum speed of 1000, 1250, 1500 and 1750 r. p.m.

- Three sieves holes diameter of 2, 4., and $6 \mathrm{~mm}$.

- Three feeding rate of 60,90 , and $120 \mathrm{~kg} / \mathrm{h}$.

\section{C - Measurements;}

Evaluation of crushing machine was performed taking into consideration the fallowing indicators:

\section{1 - Crushing capacity and efficiency:}

The theoretical crushing productivity $\left(\mathrm{T}_{\mathrm{pc}}\right)$ of the machine is the rate of productivity if the machine performed $100 \%$ of the instant time. The actual crushing $\left(\mathrm{A}_{\mathrm{pc}}\right)$ of the machine is the actual rate of productivity by the amount of actual time consumed in operation. The crushing efficiency $\left(\boldsymbol{\eta}_{\mathrm{p}}\right)$ was calculated using the following equation:

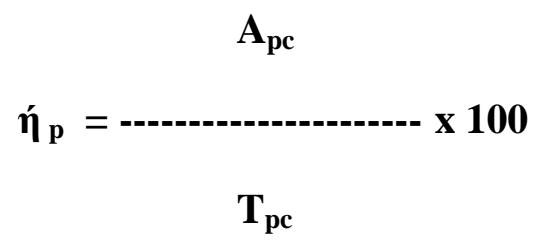

Where:

$\boldsymbol{\eta}_{\mathrm{p}}$ : The crushing efficiency, \%

$\mathrm{T}_{\mathrm{cc}}$ : The theoretical machine capacity, $\mathrm{Mg} / \mathrm{h}$.

$\mathrm{A}_{\mathrm{pc}}$ : The actual machine capacity, $\mathrm{Mg} / \mathrm{h}$

\section{2 - Faba bean crushing size mean:}

- The faba bean mean particle size ( $\mathrm{mm}$ ) was measured by using different sizes sieves "Ci" (mm) and weighting the weight over each sieves "Wi" (gm) where $\mathrm{i}$ is the sieve number and the following equation were used (Finch. 2009). 


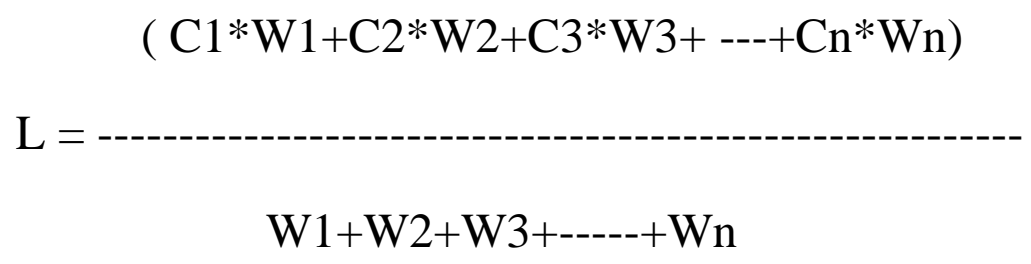

\section{3 - Crushing power requirements:}

A digital AVO meter was used for measuring the current Amber before and during experiments the total consumed electric power under machine working load $(\mathrm{kW})$ was calculated according (Lockwood and Denstan, 1971) by the following equation.

Total consumed power $=$ load + No load power

$$
\text { ( I. V.í. Cos } \theta \text { ) }
$$

Power $=$

1000

Where:

I : Current strength in Amperes.

$\mathrm{V}$ : Voltage strength (equal to $220 \mathrm{~V}$ ).

$\operatorname{Cos} \theta$ : Power factor (equal to 0.85 ).

$\eta_{\mathrm{m}}$ : Mechanical efficiency assumed to be (95\%)

\section{4 - Specific energy requirement}

The specific energy requirement ( $\mathrm{kW} . \mathrm{h} / \mathrm{Mg}$ ) was calculated by using the following equation:

$$
\mathrm{CE}=\frac{\text { Power }(\mathrm{kW})}{\text { Productivity }(\mathrm{Mg} / \mathrm{h})}
$$

\section{RESULTS AND DISCUSSION}

\section{- Effect of hammer speed on crushing machine productivity;}

Fig. (2) Illustrated the relationship between crushing machine productivity " $\mathrm{A}_{\mathrm{pc}}$ " (kg/h) and hammer speed "Hs" (rpm) at different feeding rates and sieves holes diameter. The obtained data showed that 
the curshing unit productivity increased with increase of both feeding rate, sieves holes diameter and hammer speed.

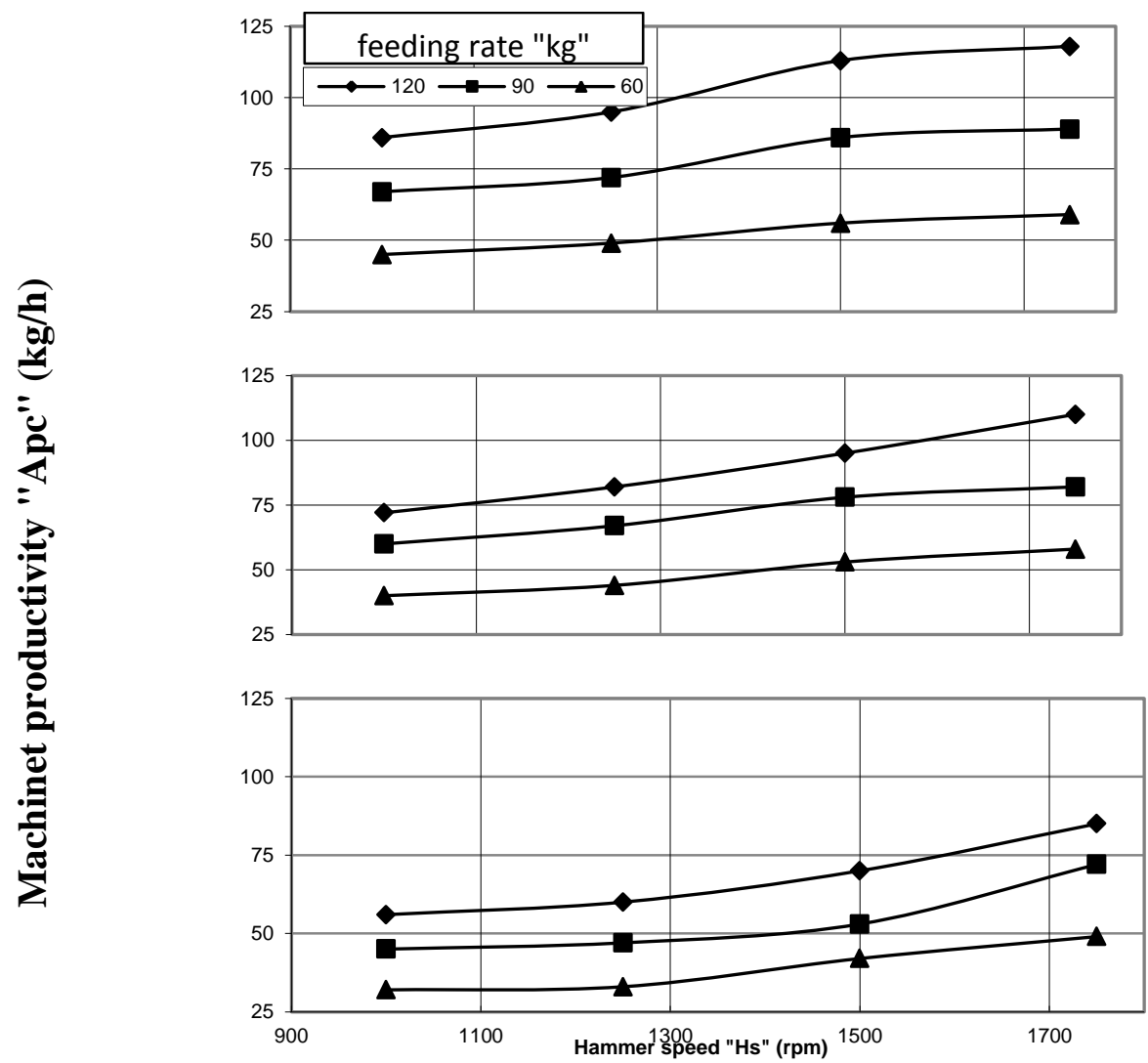

Fig . (2): Crushing machine productivity "Apc" (kg/h) Vs hammer speed "Hs" rpm at different feed rate and sieves holes diameter.

The maximum value of the crushing machine productivity $118 \mathrm{Kg} / \mathrm{h}$ at feed rate $120 \mathrm{~kg} / \mathrm{h}, 6 \mathrm{~mm}$ sieves holes diameter and $1750 \mathrm{rpm}$ hammer speed: while the minimum value of the crushing machine productivity 32 $\mathrm{Kg} / \mathrm{h}$ at feed rate $60 \mathrm{~kg} / \mathrm{h}, 2 \mathrm{~mm}$ sieves holes diameter and $1000 \mathrm{rpm}$ hammer speed.

\section{- Effect of hammer speed on faba bean mean particle size.}

Fig. (3) illustrated the relationship between faba bean mean particle size "Pz" (mm) and hammer speed "Hs" (rpm) at different feeding rate and sieves holes diameter. The obtained data showed that the faba bean mean 
particle size decreased with decrease of both feeding rate and sieves holes diameter with the increase of the hammer speed.

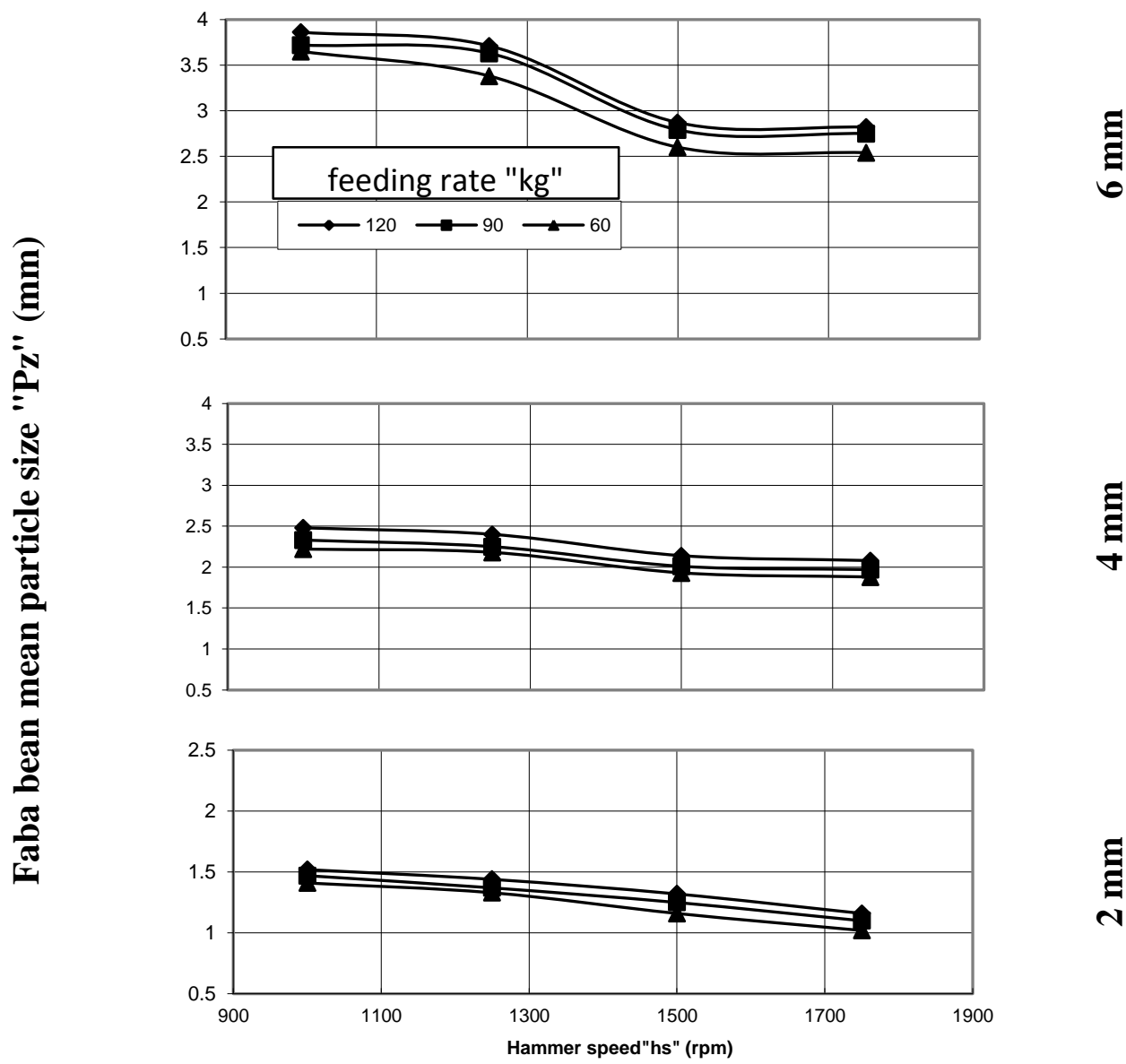

Fig (3). Faba bean mean particle size "Pz" (mm) Vs hammer speed 'Hs" (rpm) at different feed rate and sieves holes diameter.

The minimum value of the faba bean mean particle size $1.02 \mathrm{~mm}$ at feed rate $60 \mathrm{~kg} / \mathrm{h}, 2 \mathrm{~mm}$ sieves holes diameter and $1750 \mathrm{rpm}$ hammer speed: while the maximum value of the faba bean mean particle size $3.86 \mathrm{~mm}$ at feed rate $120 \mathrm{~kg} / \mathrm{h}, 6 \mathrm{~mm}$ sieves holes diameter and $1000 \mathrm{rpm}$ hammer speed .

\section{Effect of hammer speed on crushing unit requirement energy:}

Fig. (4) illustrated the relationship between requirement energy "Ce" (kW.h/Mg) and hammer speed "Hs" (rpm) at different feeding rate and 
sieves holes diameter. The obtained data showed that the requirement energy decreased with increase of both feeding rate, sieves holes diameter and hammer speed.

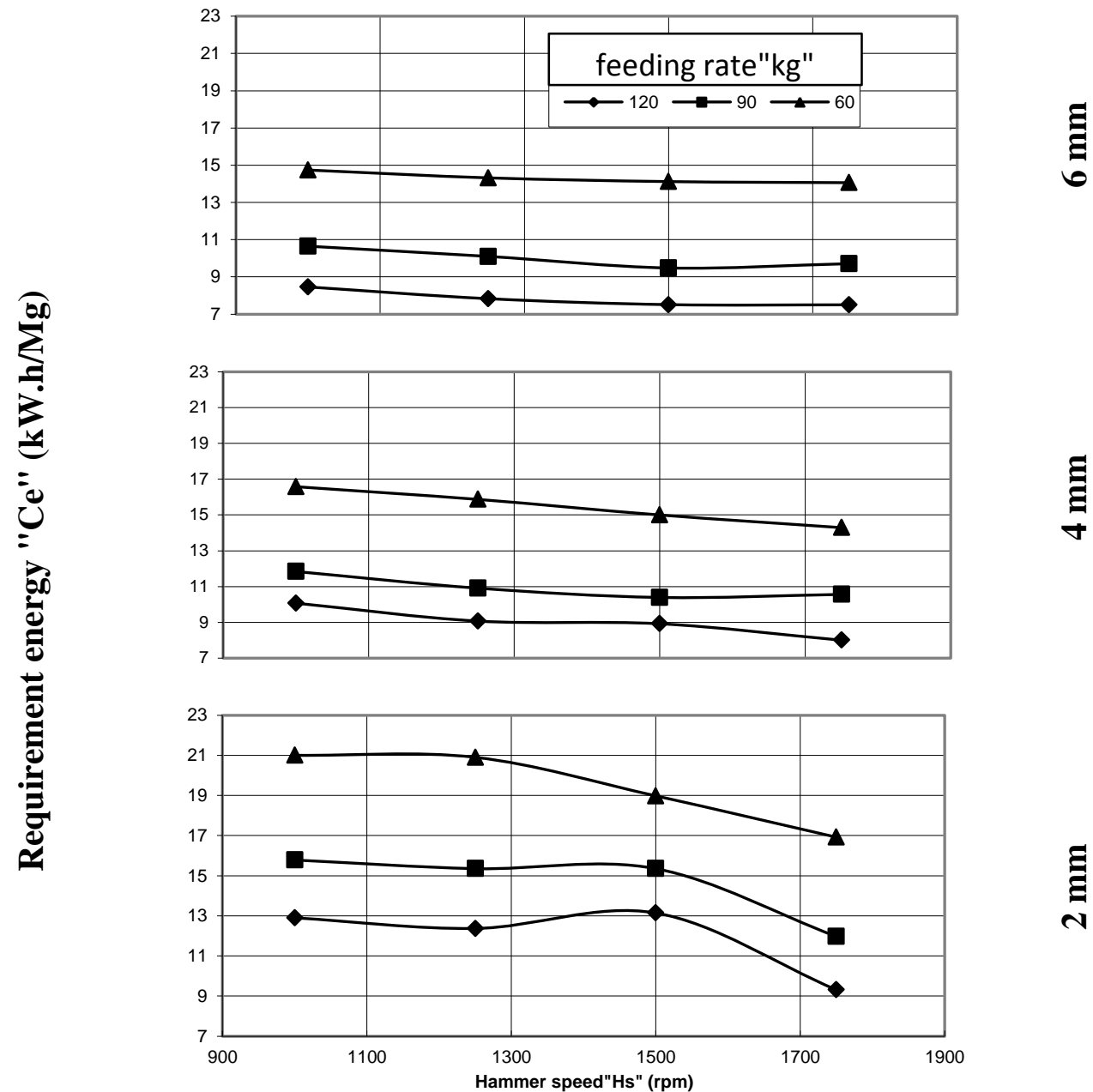

Fig 4). Crushing machine requirement energy "Ce"(kW.h/Mg) Vs hammer speed "|Hs" (rpm) at different feed rete and sieves holes diameter.

The minimum value of the requirement energy $7.50 \mathrm{~kW}-\mathrm{h} / \mathrm{Mg}$ at opening feed rate $120 \mathrm{~kg} / \mathrm{h}, 6 \mathrm{~mm}$ sieves holes diameter and $1750 \mathrm{rpm}$ hammer speed: while the maximum value of the requirement energy $21.00 \mathrm{~kW}$ $\mathrm{h} / \mathrm{Mg}$ at opening feed rate $60 \mathrm{~kg} / \mathrm{h}, 2 \mathrm{~mm}$ sieves holes diameter and 1000 rpm hammer speed. 


\section{CONCLUSION}

1 - The maximum value of the crushing machine productivity was 118 $\mathrm{Kg} / \mathrm{h}$ at feed rate $120 \mathrm{~kg} / \mathrm{h}, 6 \mathrm{~mm}$ sieves holes diameter and $1750 \mathrm{rpm}$ hammer speed: while the minimum value of the crushing machine productivity $32 \mathrm{Kg} / \mathrm{h}$ at feed rate $60 \mathrm{~kg} / \mathrm{h}, 2 \mathrm{~mm}$ sieves holes diameter and $1000 \mathrm{rpm}$ hammer speed .

2 - The minimum value of the faba bean mean particle size $1.02 \mathrm{~mm}$ at feed rate $60 \mathrm{~kg} / \mathrm{h}, 2 \mathrm{~mm}$ sieves holes diameter and $1750 \mathrm{rpm}$ hammer speed: while the maximum value of the faba bean mean particle size 3.86 $\mathrm{mm}$ at feed rate $120 \mathrm{~kg} / \mathrm{h}, 6 \mathrm{~mm}$ sieves holes diameter and $1000 \mathrm{rpm}$ hammer speed ..

3 - The minimum value of the requirement energy $7.50 \mathrm{~kW} \mathrm{~h} / \mathrm{Mg}$ at feed rate $120 \mathrm{~kg} / \mathrm{h}, 6 \mathrm{~mm}$ sieves holes diameter and $1750 \mathrm{rpm}$ hammer speed: while the maximum value of the requirement energy $21.00 \mathrm{~kW} \mathrm{~h} / \mathrm{Mg}$ at feed rate $60 \mathrm{~kg} / \mathrm{h}, 2 \mathrm{~mm}$ sieves holes diameter and $1000 \mathrm{rpm}$ hammer speed.

\section{REFRENCES}

El-Gayar and Bahnas (2002) studied some factors affecting on hammer mill to produce garlic power such as three hammer tip speeds

El-Hadid, Y. M. S. A, Hamad, A. M., Khourshid, and K. E., Hegazy, (1996) Developing a cereal milling machine. Misr J . Ag., 13 (1) : $85-100$.

Finch, T. (2009). Incremental calculation of weighted mean and varianceUniversity of Cambridge. $\quad \underline{\mathrm{https}} / / / \mathrm{scholar}$. Google.com.eg/scholar?Q=Incremental+calculation+of+weighted+ mean+and+variance+University + of + Cambridge\&btnG $=\&$ as_sdt $=0$ $\underline{\% 2 \mathrm{C} 5>}$

Garg. S. K.; \#u. C. Lohani. And J. p. Pandey ( 2010).Studies on continuous grinding process for dried water chestnut kernel. Journal of Engineering Science and Technology 5(2): 140-150.

Hegazy, K. E..S., A.O. El-Ashhab, B.A. Hemeda and MosA, m.a. Magda, (2002) Preparation and conversion of eggshell as hatchery 
by-product wastes to produce untraditional poultry feeds. Misr. J. Ag. Eng., 19(2): 958-972.

Hassan, M. A. (1994). 'Modifying and evaluating a small locally made mix-milling unit suitable for Egyption poultry farms' Mis, J. Ag. Eng., 11 (2) : 569-584.

Kozmin , P . A . ( 1988 ) Flour milling - Coerge Routledge of sons LTD - New yourk . D . Van Nostrand Company.

Lockwood, F. B and R. Dunstan (1971). Electrical engineering principle minimum. Educational books Ktd. London. (C.f Tayle et.al 2011).

Mousa et al.,( 2016). Some engineering factors affecting date pits crushing. M. Sc. Thesis, Fac. of Agr. Eng., Al-Azhar Uni.

Ministry of Agriculture and Land Reclamation ( 2012). Cropping area and production of winter crops (2002-2001), No. (5-3), Cair, Egypt.

Singh, A.K., N. Chandra, R.C. Bharati and S.K. Dimree (2012). Effect of seed size and seeding depth on faba bean ( Vicia faba L.) Productivity. Environ. Ecology, 28:522-1527.

Youssef, M. M., W. Bushuk: E. D. Murray: R. illman and A. M El Tabey Shehata (1982) : Relationship between cook ability and some chemical and physical properties of faba beans . J. Food Sei., 47: 1695- 1697 and 1709.

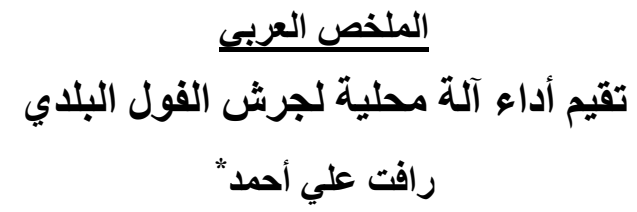

يعتبر الفول البلدي من أهم المحاصيل البقولية في مصر من حيث المساحة المنزرعة والإنتاج

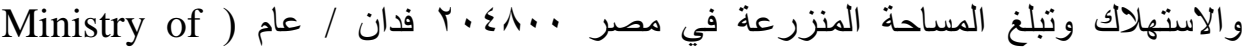
(Agriculture, 2012

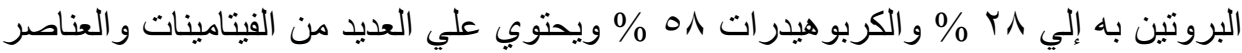

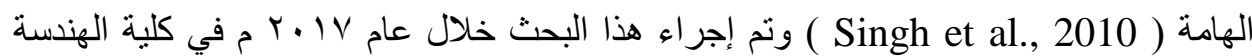
الزراعية جامعة الأزهر. ويهدف هذا البحث إلي جرش الفول البلدي للاستفادة منة في تكوين

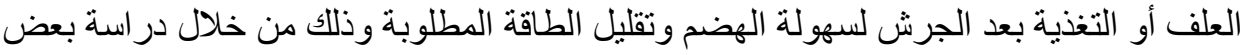
العو امل المؤثرة علي جرش الفول البلاي باستخدام آلة صغيرة محلية الصنع رخيصة الطئة الثمن يمكن ل اللمز ارع المصري المتنائها.

**:أستاذ مساعد- كلية الهندسة الزراعية - جامعة الأزهر - القاهرة 
وللوصول إلي هذا الهدف نم دراسة الأتي:

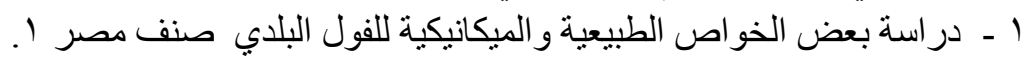
r - استخدام آلة محلية لجرش الفول البلدي تناسب الكميات الصغيرة وذات تكاليف اقتصادية بسيطة وسهلة الصيانة. r - دراسة أهم العوامل الهندسية التي تؤثر علي أداء وكفاءة آلة الجرش وهي

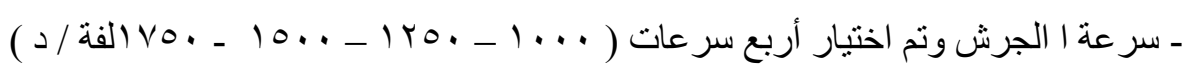

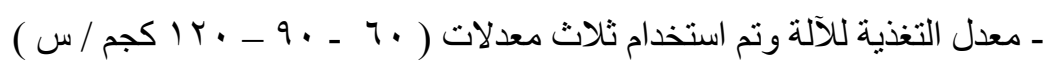

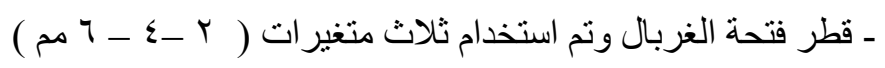

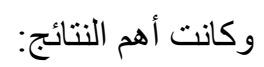

أوأوضحت النتائج أن إنتاجية الجرش تزيد مع زيادة سرعة الجرش لكل أقطار الغرابيل

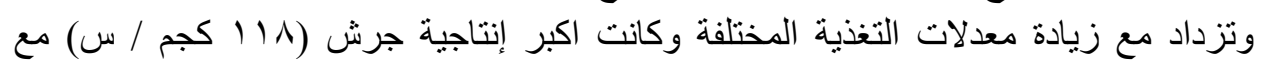

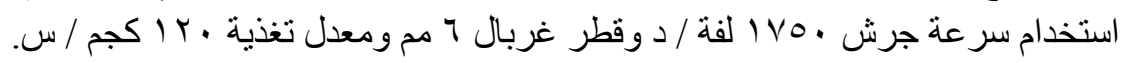

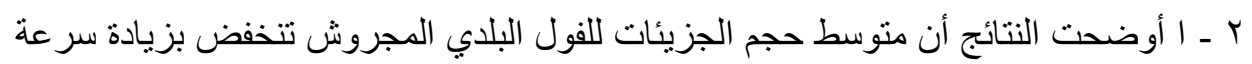

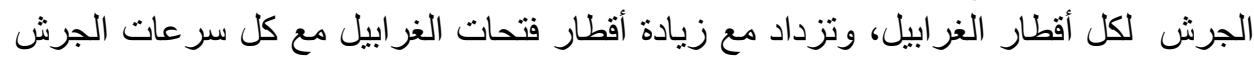

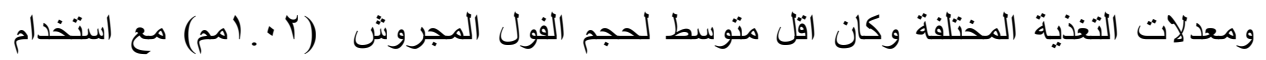

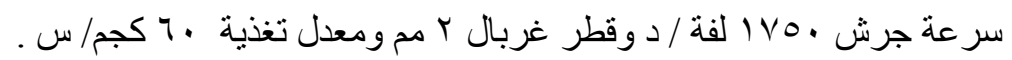

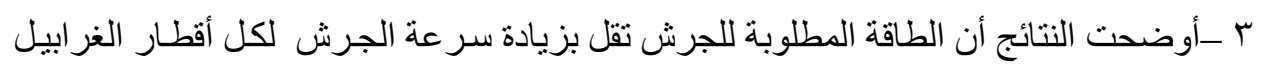

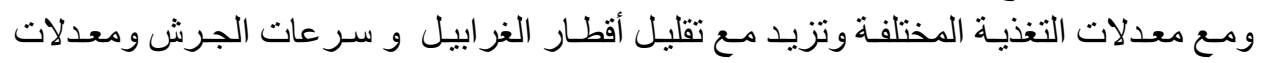

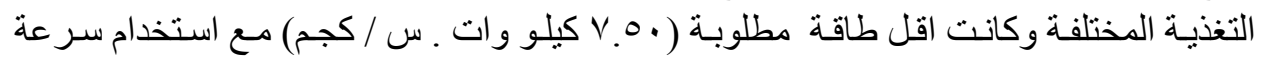

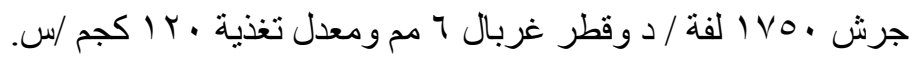

